\title{
Migration and Popular Resistance in Rural China: Wukan and Beyond
}

\author{
Yao $\mathrm{Lu}$ \\ Wenjuan Zheng \\ Wei Wang
}

\section{Full citation:}

Lu, Yao, Wenjuan Zheng, and Wei Wang. 2017. "Migration and Popular Resistance in Rural China: Wukan and Beyond.” The China Quarterly 229:1-22.

Acknowledgement: The authors thank Ran Tao, Guobin Yang, Shamus Khan and the anonymous reviewers for their helpful comments at various stages of this research. 


\title{
Migration and Popular Resistance in Rural China: Wukan and Beyond
}

\author{
Yao Lu*, Wenjuan Zheng ${ }^{\dagger}$ and Wei Wang ${ }^{\ddagger}$
}

\begin{abstract}
This study draws on a case study of Wukan and interviews with migrants and peasants in other sites to examine how migration shapes popular resistance in migrant-sending communities (i.e. rural China). Findings demonstrate multidimensional roles played by migrants and returned migrants who act as a vehicle of informational and ideological transmission and at times directly participate in or even lead rural resistance in origin communities. Both the transmission and participation processes foster political consciousness and action orientations among peasants. The importance of migrants is exemplified in the Wukan protests but is also found in other settings under study. In general, migrants represent a latent political force that acts upon serious grievances back home. The findings provide a useful lens for understanding the diffusion of popular resistance and the linkage between urban and rural activism in China.
\end{abstract}

Keywords: migration; migrants; popular resistance; protest; rural China; Wukan

On a cloudy day in September 2011, more than 3,000 villagers marched through Wukan 乌坎, a once tranquil fishing village in Guangdong province. Holding metre-long banners and clanging drums and gongs, the protesters chanted "return our farmland" as they marched towards the township government. This marked the beginning of the months-long Wukan protests, one of the most high-profile incidents of popular resistance in China and one that won rare concessions from the state authorities. ${ }^{1}$ Existing research has demonstrated a myriad of factors contributing to Wukan's success, including its massive scale, its unique timing (which coincided with provincial leadership transition), and perhaps most important, its effective use of social media. ${ }^{2}$ Less attention has been paid to interrogating who spearheaded the protests and what conditions fostered the large-scale, sustained mobilization.

The present study focuses on the neglected role of migrants and argues that examining this aspect helps to answer crucial questions regarding the emergence and development of the Wukan protests. Wukan, like many other ordinary villages in China, is characterized by large out-migration. Young people and employable men seek work in the cities while the elderly and women with children remain behind. During the protests, however, there was a notable number of young migrants, who supposedly should have been working outside the village, among the crowds. This raises an interesting question about the role migrants played in the Wukan uprising, and more broadly, about the connection between migration and rural resistance in other parts of China.

The question is intertwined with two profound transformations in China. One is the massive internal migration from the countryside to the urban centres. The migrant population is currently estimated at more than 160 million. ${ }^{3}$ This migration stream exists in the context of rigid institutional barriers created by the hukou system, ${ }^{4}$ which effectively denies rural migrants urban citizenship. ${ }^{5}$ The structural exclusion has generated a high level of circular and return migration

\footnotetext{
* Columbia University. Email: y12479@columbia.edu (corresponding author).

${ }^{\dagger}$ CUNY Graduate Center.

${ }^{\ddagger}$ University of Southern California.
} 
and reinforced migrants' attachments to families and farmland left behind. ${ }^{6}$ The farmland, which provides a critical means of social and economic security, provides migrants with a place to return to in times of unemployment and retirement. High circularity also increases migrant ties to natal villages, which is not the case for permanent out-migrants.

The second change is the surging citizen activism that has swept urban and rural China. ${ }^{7}$ While in cities, many migrants witness urban-style coping strategies among homeowners or laidoff state workers. ${ }^{8}$ At the same time, they take advantage of the internet, which is more widely available in urban areas than in the countryside and helps to circumvent tight state-mandated information control. ${ }^{9}$ As migrants become better informed, they develop a keener political consciousness and increasingly orient towards autonomous action in defending their rights. ${ }^{10}$ In the countryside, peasant autonomous action has also grown steadily. ${ }^{11}$ These actions are largely aimed at defying official malfeasance on issues such as coercive land requisition or unauthorized taxation and mostly consist of petitioning against local cadres or staging protests or other direct forms of resistance. ${ }^{12}$

Currently, there is an absence of scholarship on the linkages between urban and rural protests. Thomas Bernstein and Xiaobo Lü rightly point out that rural and urban protests have been portrayed as fragmented phenomena, reflecting a deep cleavage between rural and urban sectors. ${ }^{13}$ With greater geographic mobility, there are reasons to expect that the urban-rural linkages have, to a certain extent, been restored by migrants. As rural migrants traverse rural and urban spaces, they sustain connections with home villages. They tend to acquire a unique position through which they impart to those who remain new information and awareness that can reshape their attitudes and behaviour. They also engage in concerted efforts that assist peasant resistance. This is likely to generate political diffusion from urban protests to rural resistance.

In China, systematic research on protest diffusion is limited, with a few notable exceptions. Wu Zhang provides some of the first empirical evidence of how rural protests spread through coordination among protest leaders across multiple sites. ${ }^{14}$ In the general movement literature, attention has been paid to the importance of social movement activists and communication technology. ${ }^{15}$ One potential mechanism of diffusion, the quotidian, interpersonal communication with ordinary migrants, has not been explicitly examined. It constitutes a form of relational diffusion embedded in shared identities and interests, which, if it occurs, can exert greater influence on rural resistance than non-relational channels of diffusion (for example, via the media or leaders).

Beyond political diffusion, politicized migrants have the capacity to assume leadership positions. This study adds to the literature on protest leadership by highlighting the backgrounds of activists beyond commonly studied characteristics (for example, gender, education, personalities). A small body of work provides anecdotes of how demobilized veterans utilize their experience and organizational skills and evolve into leaders. ${ }^{16}$ Although this literature does not focus on migration specifically, migration lurks in the background of the stories. We go a step further and systematically examine the degree to which migration transforms current and former migrants into becoming leaders.

First, we conducted an extensive case study of the Wukan protests. Because these protests stand out in scale and durability, we ask whether the role played by migrants in Wukan illuminates a more general process underlying other forms of rural resistance in China. To this end, we carried out in-depth interviews with migrants and peasants across several localities in China. We do not claim that migration is the only or the most important factor in explaining the resistance, but it is a potentially crucial condition in understanding rural resistance amidst a 
multitude of factors. In general, our findings demonstrate that migrants are an important political resource for rural sending communities and that the role of migrants is conditional and multidimensional.

\section{Methods}

For the Wukan case study, we performed a content analysis of media reports and scholarly accounts of the protests. We further supplemented the analysis with in-depth interviews conducted in 2015 with two Wukan activists: a key player and an active participant in the protests. We gained access to the village through one of the author's pre-existing connections. This author had participated in a volunteer group committed to educating illiterate women in Wukan and has since stayed in contact with the local organizers of the volunteer group. One organizer became our informant and put us in contact with other activists. This connection gave us unique access to the village and facilitated high-quality interviews. In this article, we use real names for activists who maintain a public profile and pseudonyms for others.

To understand the role of migrants in the everyday struggles of peasants beyond Wukan, we draw on semi-structured interviews with migrant workers and peasants conducted in 2015. These interviews further elucidate the complex conditions and mechanisms underlying their roles. The interviews with migrants were conducted in two cities located in the primary migratory destinations, namely Shenzhen 深圳 (Pearl River Delta) and Hangzhou 杭州 (Yangtze River Delta). ${ }^{17}$ Interviewees were found through local labour NGOs that connected us to migrants working in the area. The fieldwork entailed mostly one-to-one interviews with migrants, with the exception of two focus-group interviews and one interview with an NGO leader, a migrant who later became a labour activist. Our questions focused on the respondents' experiences, their connections with origin families, and local resistance in their hometowns. In one case, we spoke on the telephone with the left-behind spouse of a migrant. We completed 19 interviews.

The interviews with peasants were conducted in four villages in Jiangsu 江苏 and Fujian 福建 provinces (two villages in each province). Both provinces have experienced large outmigration flows. The villages were selected because one author was involved in a previous survey in these sites, which facilitated our access to the villages. We conducted 21 interviews, focusing on contact between peasants and their migrant family members as well as local grievances and resistance in the villages. Both migrant and peasant interviewees are anonymized to ensure confidentiality.

\section{Wukan: A Case Study}

Synopsis

The Wukan protests consisted of a series of anti-corruption protests in 2011 triggered by illegal land sales. Between 1993 and 2011, the village committee had sold over 2,000 acres of collective land to real estate developers, generating more than 700 million yuan in revenue. ${ }^{18}$ Wukan villagers were never informed about the land deals and were denied compensation. The huge profits were pocketed by village cadres. ${ }^{19}$ Grievances began to accumulate after the villagers were made aware, in April 2009, of illegal land transactions through an open letter entitled "A letter to fellow villagers of Wukan: we are not slaves of a dead village" (Gei Wukan xiangqinmen de yifeng xin: women bushi wangcunnu 给乌坎乡亲们的一封信 - 我们不是亡村奴). ${ }^{20}$ The letter, written and distributed throughout the village by "Patriot No.1," disclosed the illegal sales 
and urged villagers to reclaim their land. ${ }^{21} \mathrm{~A}$ contact number for QQ (a popular instantmessenger in China) was given in the letter. This initiated a series of petitions to higher-level officials.

In 2011, when land developers began construction on the last large piece of land in the village, local anger was finally unleashed, giving rise to the September protest. ${ }^{22}$ The protest began as a peaceful demonstration and escalated into a direct confrontation with police, who had been dispatched by local authorities to maintain order. A group of young villagers caught the clashes on camera and later used the footage to make a documentary entitled, "Wukan! Wukan!" 23 Local authorities attempted to pacify protesters by allowing villagers to elect an interim 13-member village council. ${ }^{24}$ The authorities promised to conduct an official investigation and work with the council members to find a resolution, a promise which they failed to deliver on. In November, a second protest broke out. This time, villagers demanded intervention from higher-level authorities. ${ }^{25}$ The protest was violently repressed and five protest leaders were detained.

Tensions escalated further after one of the detained leaders, Xue Jinbo 薛锦波, died in police custody. ${ }^{26}$ Outraged villagers expelled the official village committee and the police, a move which instigated a stand-off with the local government in December. ${ }^{27}$ The intense weeklong stand-off ended after the provincial government intervened and agreed to meet the villagers' demands, including a democratic election and a full investigation into the corruption as well as Xue's death. A democratic election of new leaders was held in February 2012.

\section{Young migrants: informed and emboldened instigators and activists}

How did Wukan villagers become informed and effectively organized? Who spearheaded and sustained the collective resistance? As our research reveals, the actions were carefully planned by a group of migrant activists. They informed and spurred the villagers into action and became foot soldiers themselves in the protests. Because Wukan is located in Guangdong, the primary destination province for migrants, migration has been an integral feature of the village. A large proportion of villagers under the age of 50 have spent some part of their lives working in the province's cities. ${ }^{28}$ Among them is Zhuang Liehong 庄烈宏, the mysterious “Patriot No. 1,” who composed and distributed the open letter which effectively sparked the Wukan uprising. ${ }^{29}$

Back in 2009, Zhuang, a migrant in his thirties, had worked his way up to be the owner of a small business in Shunde 顺德, Guangdong. During our interview, Zhuang openly acknowledged how the migration experience had transformed him and ultimately spurred him into action: "If I didn't go outside the village and work in places like Shenzhen, Foshan 佛山, and Shunde, I wouldn't have returned to Wukan to do this [protest]." ${ }^{30}$ While in Shunde, Zhuang learned to surf the internet. One of the first things he did was to search for references to his hometown. The search turned up a news article under the headline, "Wukan, a bright Binhai pearl," which explained how village cadres had lifted the entire village out of poverty through industrial and land development. Zhuang realized that the article was false. Ordinary villagers like him had not benefited from the land development. He was further surprised to learn about the land rights that local residents in Shunde enjoyed. Shunde residents had been earning sizable dividends from leasing out their collective lands. Zhuang had a revelation: "Before leaving the village, we are all like frogs in a well (jingdi zhiwa 井底之蛙) ... Those people [in Shunde] can live on dividends from collective lands. I had always thought that the land in the village [Wukan] belonged to the Party secretary. He could deal with the land however he wished." "31 "The several 
years that I lived in Shunde have changed me. I slowly discovered that we, as peasants in Wukan, have been unfairly treated." 32

His perception of injustice and a new consciousness of peasant land rights prompted Zhuang to stand up for his village. He carefully drafted an open letter, framing the land sales as illegitimate. He strategically chose to distribute the letters the night before Tomb-Sweeping Day (Qingming festival). The festival is a major event when many migrants are expected to return to their home villages. Zhuang took advantage of the holiday to reach a wider audience, and in particular, migrants who shared a similar experience. In his own words, the letter and the subsequent village-wide discussion that it triggered played a crucial role in "inculcating a sense of rights and responsibilities in ordinary villagers." 33

After the letter was circulated, Wukan villagers, many of whom were migrants living outside the village but who were connected via the internet, linked up with "Patriot No. 1" via QQ. Zhuang shared his experience and views online: "Their land [Shunde] is rented out as a collective, and they share income as a collective ... Why do other people have this but we Wukan folks don't? ... Our rightful benefits have been infringed upon." 34 The information disseminated online revealed to the villagers the injustice of their situation. Consequently, grievances surfaced and motivated them to join the cause. Beginning with the open letter and online discussion, Zhuang made conscious efforts to frame the issue in ways that fostered a shared understanding and legitimated collective resistance.

As more people joined the discussion, Zhuang formed an online group called the Wukan Hot-blooded Patriotic Youth League (Wukan rexue qingniantuan 乌坎热血青年团, hereafter, the League). Initially, the group was mostly composed of migrants, who remained core members of the League, but later expanded to include other villagers. ${ }^{35}$ With membership quickly approaching a thousand, the League became the main forum for information exchange and deliberation, gradually evolving into a grassroots organization. In June 2009, Zhuang rallied League members to travel to Guangzhou and petition provincial authorities. ${ }^{36}$ Despite strong opposition from the village committee, the League managed to launch a two-year long petition campaign, which included a total of 11 petition trips to 14 government agencies at the county, municipal and provincial levels. The petitions, however, failed to elicit a meaningful response. During the process, the League grew distrustful of higher levels of government and the formal petition system. This prompted a shift in tactics (i.e. protests) in 2011.

Zhuang had been commuting between Wukan and Shunde during the petitioning campaign. In 2011, he moved back to Wukan permanently to devote himself to the struggle, as did several other key members of the League. ${ }^{37}$ For them, the key to encouraging village-wide mobilization was to bring information and new consciousness from outside to inform and empower villagers. The League "broadcasted video discussions and distributed leaflets and songs which stressed corruption and evoked resistance."38 Together with the interim village council, the League also convened village assemblies to disseminate information and reinforce a strong sense of consciousness and collective responsibility. ${ }^{39}$ These public activities were combined with the interpersonal mobilization of the families and friends of League members. Moreover, the League facilitated cross-lineage coalitions among three large clans and a few dozen small clans in Wukan. ${ }^{40}$ All of these efforts provided the underpinning for a large-scale protest. The commitment of key League members inspired many other migrants and villagers to join the action. By the second round of protests, the number of participants, including migrants who had returned to take part, had increased substantially. ${ }^{41}$ 


\section{Return migrants: experienced leaders and intermediaries}

Whereas young migrants spearheaded the initial stages of resistance, as time went on a group of senior villagers emerged as a potent force in the protests. Many of the senior activists were once migrants and had returned to the village, reflecting a pattern seen among the first generation of Chinese migrants. These migrants left for cities in the 1980s but found opportunities for permanent settlement there to be extremely limited. ${ }^{42}$ Since the 2000 s, they have begun to return home in large numbers after retiring from migratory work. It is estimated that return migrants represent 6.3 per cent of the rural labour force and 28.5 per cent of the total migrant population. ${ }^{43}$ With accumulated human capital and wealth, many command considerable prestige, which is key to mobilizing villagers.

In Wukan, the older return migrants (or returnees) complemented the efforts of young migrants. One channel was through running the interim village council. Many of the 13 elected council members were return migrants. Lin Zuluan 林祖栾, a key protest leader and the head of the council, worked for years as a merchant in cities; Yang Semao 杨色茂, another key leader, spent years working as a manager in a company in Shenzhen. ${ }^{44}$ Xue Jinbo, the leader who died in police detention, had worked outside Guangdong before returning in the 2000s.

Years of urban experience had transformed these returnees into emboldened activists who demanded better local governance. ${ }^{45}$ They were also particularly attached to their native soil now that they had settled back. As Yang Semao put it: "When I returned, it became clear to me that things are getting worse here." 46 In the election, he used the campaign message: "Keenly aware of shady village governance. Hope to use democratic election to change the reality." 47 Lin Zuluan also articulated a strong perception of rights: "I want to be able to express my opinions to officials ... I have that right. We all have that right." ${ }^{48}$ The presence of these returnees served as a source of inspiration for other villagers.

The returnees leveraged their experience and personal prestige to mediate between aggrieved villagers and local governments during the protests. Over time, the old and young established a strategic division of labour. Young migrants maintained communications with the villagers and kept the outside world informed via social media. Much of their work was done behind the scenes. Older returnees worked in the spotlight as they took charge of organizing public protests and negotiating with the local government. ${ }^{49}$ This strategic cooperation was critical to the success of the Wukan protests. In Zhuang's own words: "Seniors are deemed more reliable. We [the League] know that to succeed, we cannot rely only on young people. We must integrate the strength of the young and the old." 50

Female return migrants also worked to assist the interim village council and protests. Ms Chen Suzhuan 陈素转 and Ms Huang are both return migrants who together established the Wukan Temporary Women Representatives' Union. ${ }^{51}$ They actively engaged in protest planning and encouraged women to share responsibilities and participate in village affairs. The activism of these women is unusual, considering that they grew up in Chaoshan 潮汕, a region long characterized by patriarchal dominance. ${ }^{52}$ What prompted these women to become activists? Huang's story sheds light on the importance of the migration experience. While working in Shunde, she witnessed how residents in a nearby village fought for their farmland. During our interview, she recounted how villagers gathered to block construction and engaged in an intense stand-off that eventually succeeded in reclaiming the land. This experience raised her 
consciousness about the power of protests. Reflecting on what she saw and the struggles back home, she asked: "why can't we get our land back?"53

Over time, a network of women, many of whom were returnees, emerged to inspire their peers in Wukan and to "spread the word" about the protests. ${ }^{54}$ As men migrated for work, women naturally became the key "knot" connecting families across the village. Indeed, women helped the interim council to deliver important information and persuade villagers to join the fight. $^{55}$

Consequently, when the village democratic election was held in 2012, returnees and young migrants became the new village leaders, ${ }^{56}$ in fact, six of the seven members of the new village committee had experienced migration (Lin Zuluan, Yang Semao, Zhuang Liehong, Hong Ruichao 洪锐潮, Zhang Jiancheng 张建城 and Chen Suzhuan).

\section{Technology-empowered migrants and technology-facilitated activism}

One key to the success of the Wukan action was the effective use of social media, making the protest a model of technology-facilitated collective resistance. ${ }^{57}$ Unsurprisingly, young migrants were behind the adoption of new technology. Facilitated by greater internet access in cities and acquired internet literacy, migrants broke through official censorship and rallied tremendous support outside the village. ${ }^{58}$

Zhuang Liehong, who launched the QQ forum, first learned to surf the internet while working in the city. At the initial stages of the protest, the League's online forum was the centralized source of information, which protected against misinformation and intentional distortion by local authorities. ${ }^{59}$ The virtual space also allowed villagers to communicate and coordinate not just among themselves but also with migrants outside the village, bolstering a sense of collective identity and responsibility. When the first protest broke out, the League effectively used social media to make its struggles known to a broader audience.

Another media-savvy activist was Zhang Jianxing 张建兴, a 20-year-old migrant in Shunde and a key League member working alongside Zhuang Liehong. ${ }^{60}$ Zhang quit his job as a mobile phone salesman in Guangzhou and returned to Wukan during the first protest. With the media skills he had acquired in the city and the funds donated by villagers, he purchased a video camera and recorded all major actions in Wukan. He and 11 other League activists worked in shifts to post videos, pictures and updates on Weibo each step along the way. They turned their video footage into the documentary, Wukan! Wukan! They organized public viewings of the documentary which attracted thousands of villagers and served as a continued inspiration to sustain the mobilization. Zhang and other League members also worked with journalists, including international journalists whom he helped to sneak into the village, to bring the voice of the villagers to public attention and to fend off a violent crackdown. With help from the media, the young activists successfully framed the protests as "rightful resistance."

\section{Migrants' strong attachment to land}

The important role of migrants in Wukan is built on their persistent and strong attachment to land. For migrants, even the younger ones, land remains the main if not the only viable source of social security and elderly support. The League reiterated the message in its online forum: "As long as we still have land, we will never be poor. If all the land is sold, we will be poor temporary workers (dagong zai 打工仔) generation after generation."61 As Huang remarked 
(when referring to the online slogan): "It struck me deeply as I am also a migrant worker. Only people who have been outside know how valuable the land is... You don't earn much outside. When you come home from the city, the land is gone! How can we live without land? You will not be able to even feed yourself!"62

\section{Summary of the Wukan case}

The Wukan case illustrates the critical role played by migrants in collective resistance, as exemplified by the sustained networks of young migrants and returnees. Many of them had been exposed to and assimilated new information and consciousness during their migratory journey. Such a transformation would have been unlikely had they stayed in the village. The migrants performed multiple roles. First, they informed and inspired the villagers through the open letter, online discussion, village assemblies and interpersonal interactions. This diffusion process helped to create a community of politically conscious and engaged individuals who could be mobilized. Second, migrants participated in the protests. A number of them made an even more concerted effort by leading the protests and mobilizing villagers throughout the struggles. Third, they orchestrated collective resistance that displayed considerable resilience by combining indirect and direct tactics, using effective frames to evoke collective resonance and legitimate action, and resorting to social media for greater influence.

While these roles can be found in other places, a few factors specific to Wukan contributed to its massive resistance and rare success. One is the high level of circular migration. Because of Wukan's geographical location in Guangdong, migration opportunities are vast and migrants can stay close to home. Migration from the village had reached a peak level and involved short distances, which enhanced the migrants' ability to return and engage in village affairs when needed. These migration dynamics also facilitated diffusion throughout the community and maintenance of village cohesion.

Another factor favourable to large-scale mobilization is the organizational structure of the village, which is based on pre-existing lineages. The three large lineages (Xue, Sun and Chen) have retained amiable relationships. Inter- and intra-lineage cohesion translated into important mobilizing structures for defending community-wide benefits. In fact, the leaders activated a sense of lineage solidarity during the protests by first rallying the lineage heads who then helped to mobilize the rest of the lineage into action. Almost every family in the village engaged in traditional lineage practices such as ancestral worship. These practices reinforce collective identity and ease coordination during collective action. The fact that many villagers participated regularly in lineage events helped the orderliness of the street protests: the crowd naturally organized itself into ordered ranks when marching to the government building. The League, composed of an extensive network of activists in and outside of Wukan that undertook different tasks during the protests, functioned as a second organizational base. This organizational structure was instrumental in the large-scale mobilizations as it connected internal and external resources and complemented the efforts of the leaders. As an organizational foundation it also helped to sustain the protests in that when several leaders were detained, other League members filled the gap and led the villagers to launch continued and more forceful actions.

\section{The Perspectives of Migrants and Peasants beyond Wukan}

In this section, we look at the data garnered from in-depth interviews with ordinary migrants and peasants outside of Wukan to examine the role of migrants in other instances of rural resistance 
in other parts of the country. These instances often take different forms and achieved different scales. Furthermore, we investigate the conditions and mechanisms the underlie the roles of migrants.

\section{Transmission from and involvement of migrants: a reactive process}

Almost all migrants in our interviews deemed migration to be a liberating experience. The majority have seen fellow migrants engage in labour struggles or homeowners protest over property rights. Migrants' heightened knowledge and consciousness were keenly felt by families back home. Peasants we interviewed acknowledged migrants as worldly and informed (jianduo shiguang 见多识广). Moreover, like their Wukan counterparts, the majority of migrants we interviewed stressed their attachment to the farmland and their home village. Many planned to return after retirement: "For sure I will return, my farmland and housing land (zhaijidi 宅基地) are all there." 63 Some also cited high living expenses and limited access to social welfare as reasons to return. ${ }^{64}$

The transformative experience of migration, combined with migrants' enduring connections to their hometowns, provides the ground for migrant-driven transmission and engagement. But, this tends to be a reactive process, often activated in response to local crises. Talk about laws and rights intermittently filters into regular communications between migrants and families. Migrants sometimes eschew the idea of initiating politically-imbued talks or discussing their labour struggles. There are several reasons. First, migrants worry about causing unnecessary concerns among left-behind family members, especially those who may not be fully aware of their plight. As a result, there is a generational difference, with political transmission occurring more commonly between migrants and those in the same generation (for example, spouse, siblings and friends) than between those from different generations (for example, parents). ${ }^{65}$ Second, some migrants considered the disclosure of their labour struggles as a sign of trouble, which would cause their families to lose face. An interviewees' girlfriend back home broke up with him after learning about his involvement in a collective petition. Third, migrants cited long working hours and inflexible schedules as a deterrent to having an in-depth discussion about political issues with families back home or returning to help out. On the other end, family members sometimes refrained from informing migrants of minor issues at home to avoid overburdening them. Overall, there is a tendency for migrants and families to drift apart.

It is a different picture, however, when trouble arises in origin communities, for instance, when villagers fall victim to land requisitions or unauthorized taxation. Such troubles put not only the interests of peasants at stake but also those of the migrants. In this scenario, migrants and peasants have to work together to resolve problems. This prompts transmission and the engagement of migrants, and compels those who remain to seek help from migrants. An NGO leader reflected on his experience working with migrants:

Although migrants work away from home, they are essentially part of the family. Families really rely on migrants ... So when problems arise in the village, peasants will contact migrants and discuss the situation. They often ask migrants to make decisions (zuozhu 做主), to help out (bangmang 帮忙), or to offer ideas (chuzhuyi 出主意) ... Parents act this way because their interests are closely related to the interests of their children [the migrants]. ${ }^{66}$

Looming local crises often spontaneously invoke a sense of responsibility among migrants, who, upon learning about problems back home, engage in communication with their families or return to resolve the issues. ${ }^{67}$ Their decision to become involved comes an awareness 
of the rural-urban information gap: "People in the village are far away from cities. They have few means to obtain information and really understand things. Only we who have been to the outside world have the knowledge to help."68

To those migrants who were fortunate enough to be spared the problems back home, we posed a hypothetical question: what would they do if their families fell victim to land requisition or unlawful taxation? The reaction was unanimous and demonstrated a strong will to assist villagers. One migrant worker maintained: "For sure I would go back to my village to deal with the issue. Everyone knows about me and my experience in the city ... If I lack the knowledge, I will get help from others who can check the policies and provide advice."69

\section{Multiple dimensions of transmission and engagement}

The processes and forms of transmission and engagement of migrants are multidimensional. They can include the transmission of policy information and diagnosis of local violations, ideological transmission that instils stronger consciousness and action orientations, obtaining and giving concrete advice on laws and tactics, and direct participation in rural resistance.

A particularly illustrative example came to light through our interviews with Wang, a migrant, and his wife back home. ${ }^{70}$ Wang engaged in regular phone communication with his wife and shared his labour struggles and new perspectives with her. These exchanges intensified when public schools in his hometown began to collect unauthorized fees from students' families (despite state-mandated free compulsory education). The fees, which cost over 1,000 yuan per year, imposed a heavy burden on the family. Wang's wife raised the subject during their phone calls. Wang immediately sensed something was wrong: "There is now a law that local governments cannot impose arbitrary fees. If this happens, you can complain to the government." my husband encouraged me to take action, I thought, okay, everyone pays the fee ... I will pay as well. Now, I know that I can, and should, defend my own rights."72

Wang suggested further strategies: "Complaints from one person will not work well. It works better if a group of people complain." Following his advice, Wang's wife mobilized a group of parents to lodge complaints with the local education department. She spread the word to other villagers: "We can complain about arbitrary fees to the government. If we do, they will send people to resolve this issue ... A few of us complain today, and a few complain tomorrow, the education department will take notice and investigate this issue. We can even bring our children to the government. This will be very effective." $" 73$ In this case, the migrant provided information on policies that prohibited excessive fees, inspired his wife to take action, and suggested effective strategies, such as collective instead of individual action and, if necessary, staging a more dramatic action by bringing children to the government.

In China, government policies provide the aggrieved with a political opportunity. Migrants often learn about these policies before the peasants who remain in the villages. An incident in a village in Jiangsu illustrates the role migrants can play in disseminating information and raising consciousness. ${ }^{74}$ In 2011, the local municipal government paid the village committee more than 500,000 yuan to acquire $15 \mathrm{mu}$ (10,000 square metres) of land for the construction of a nursing home. The villagers whose land was acquired, however, received no compensation. In this situation, a migrant spoke out. In village-wide meetings, he shared his knowledge about land policies and used government documents he had accumulated in the city to convince the villagers that local governments acted in violation of national policies. He also invoked the ambiguity of 
land ownership ("collective") to accentuate peasants' land rights and motivate villagers to take action: "The land belongs to peasants. If someone wants to use the land, they must compensate us." Feeling emboldened, the villagers took to the streets and blocked the construction site. The municipal government conceded, and the villagers received compensation of 390,000 yuan.

Return migrants can act as a readily available political resource, which is especially important because they share the same concerns as other villagers. For example, in a village in Fujian province, a return migrant learned about plans for land requisition and compensation packages. ${ }^{75}$ He not only helped to identify the issue - that the compensation offered was below national and local standards - but also raised the consciousness of exploited peasants: "They [local officials] need to respect our rights first. Then they can lease our land." Subsequently, the villagers launched a collective petition to the township government. The migrant also assisted in this by preparing petition documents and citing national policies to justify village claims. Over time, the return migrant became the go-to local activist. He enjoyed a reputation for "knowing more about the outside world ... and how to deal with local officials (da jiaodao 打交道).”

Beyond informational and ideological transmission, migrants may engage in concerted efforts and become the defenders of peasant interests. On a return visit to his home, a Shenzhen migrant heard a rumour that the township government had pocketed funds that should have gone to the peasants in the form of direct agricultural subsidies (nongye zhibu 农业直补). ${ }^{76} \mathrm{He}$ immediately realized that it was unlawful to withhold these subsidies from peasants. He checked online and with the local agricultural bureau about the availability and standards of the subsidies in his region. Feeling obligated to help elderly peasants, he instigated a formal complaint to the county government in which he pinpointed the policies that were violated. In the meantime, he helped a group of elderly peasants to issue collective complaints to the township government. This series of actions led to an official investigation and the eventual return of the subsidies.

Migrants also return home during times of crisis to participate in local resistance. In a Fujian village, the expansion of a cement plant had jeopardized local farmland. The villagers organized a large-scale protest with more than 100 participants. Migrants came flocking back to join the protest, some from as far away as Hainan. Together, peasants and migrants blocked the main road and seized the bulldozers. This led the local government to terminate the plant expansion project. Reflecting on this incident, a villager noted: "At that time, there were mostly elderly people, women, and children in the village. They must call back young people and men ... Migrants would all come back. How can they concentrate at work (anxin dagong 安心打工) when their houses and land are being torn down?" 77 When migrants are unable to return, they sometimes make financial contributions to help offset petition and protest expenses. ${ }^{78}$

As discussed above, migrants provide information about relevant policies that can clarify transgressions and justify peasant resistance. The information fosters the development of "rules consciousness." 79 Migrant-driven transmission sometimes constitutes a form of "rights consciousness" that transcends the lines drawn by rule-making authorities. ${ }^{80}$ This is seen in migrant and peasant adoption of collective action and extra-institutional means (as opposed to individual action and institutionalized channels). Another indication of rights consciousness comes from the development of negative attitudes towards state institutions and rule-making authorities. We found that some migrants have begun to doubt the existing institutions: "Local officials are corrupt. But it is because the official selection and promotion system is problematic ... It really has to do with the central policy." ${ }^{81}$ This sentiment can feed back into migrantsending communities, leading to peasants becoming distrustful of central authorities and then potentially employing more direct tactics when dealing with the state: "Petition is useless, 
regardless of which level you petition to. In the end, the country is run by officials (guojia jiushi dangguande shuolesuan 国家就是当官的说了算).” ${ }^{.2}$

\section{Discussion}

Drawing on a case study of Wukan and in-depth interviews in several other sites, this study examines how migration shapes popular resistance in origin communities. Migration, which involves traversing different socio-political environments, constitutes a transformative experience, allowing many migrants to acquire new information and ideas. Over time, migrants emerge as an important political resource that can help to foster greater consciousness and autonomous action among peasants in their hometowns, who are otherwise ill-informed and quiescent in an often cellularized environment.

[Typesetter: please insert Figure 1 about here]

Our research demonstrates the underlying conditions and mechanisms for the roles that migrants play in popular resistance (summarized in Figure 1). Migrants tend to serve as a latent resource. Their roles operate largely in a reactive process: they are commonly activated in response to local crises, especially when the interests of peasants and migrants are at stake. By contrast, routine communications between migrants and families that carry a political message occur less often.

The roles of migrants are multidimensional. First, migrants act as a vehicle of informational and ideological transmission. The process transpires via long-distance communications or in-person interactions with current and return migrants. Community-wide spillover may also arise through local networks encompassing friends and families of migrants. Migrant-driven transmission helps to inculcate a stronger sense of political consciousness, creating a community of informed and emboldened individuals. Second, migrants play a more visible role through direct political engagement. Migrants and returnees sometimes leverage their resourcefulness to mobilize and lead fellow villagers throughout their struggles. At other times, they participate in resistance led by others to show their support.

The political importance of migrants is exemplified in Wukan, where migrants weaved their multiple roles (direct and indirect) into a massive-scale collective resistance. The high degree of circular migration combined with the existing mobilizing structures within the village make migrants a particularly effective force in Wukan. In other words, the success achieved by Wukan resulted from pooling and deploying both external resources (migrants) and internal resources (pre-existing solidary structure such as lineages). But, we also find evidence for the indirect and direct roles played by migrants in other locations, although transmission seems to be more common than direct involvement. Migrants can serve as an important political resource in other parts of the country not covered in our study. Their role is likely to be especially potent in places that experience the migration patterns and social structure observed in Wukan. A largerscale study using systematic quantitative data will advance our understanding in this area. Few scholarly and media accounts, however, have paid sufficient attention to the potential roles of migrants in rural protests. This represents a crucial omission, especially given the ever-growing grievances that migrants have voiced about their home villages through social media platforms. ${ }^{83}$

Overall, our findings contribute to several strands of literature. They provide a useful lens through which to view surge in rural resistance and the linkage between urban and rural activism in China. In a way, migrants have emerged as critical allies of peasants, helping the latter to overcome the vertical barriers set up by the regime to forestall linkages between rural and urban sectors. The findings also highlight an understudied mechanism of protest diffusion: the role of 
migrants as an interpersonal venue of diffusion of information, consciousness and, ultimately, practice. Moreover, this study adds to the protest leadership literature by drawing attention to migrants whose newly acquired knowledge and skills can translate into leadership capacity.

That said, we do not intend to exaggerate the role of migrants. Rural resistance is too complicated to be explained solely by migration. The processes we uncover do not include all migrants, nor do they involve all villages. There are cases where the potential role of migrants is weakened by family separation, generational gaps, or the grim conditions facing migrants in cities. At an aggregate level, the large exodus of migrants to the cities could lead to social deterioration in origin villages, undercutting local political engagement and the capacity to mobilize. ${ }^{84}$

These concerns should not detract from the political importance of migrants. Traditional solidarity and the attachment of migrants can often be activated, if not already strong, in crisisridden villages. In some cases (for example, Wukan), the concerted efforts of even a moderate number of migrants can foment significant political change back home. Importantly, migrant involvement in origin-village politics represents a form of contention that is initiated externally by people outside the community and is gradually incorporated into the relations of migrants and villagers, eventually developing into cooperation between those on the outside and those within the community. This is a powerful model because migrants and villagers contribute complimentary resources to local resistance. The model also circumvents local repression and information control. Collective resistance that includes activists beyond the local sphere of control is less likely to be contained by local authorities than resistance lacking external allies.

State institutions in China inadvertently strengthen the political significance of migrants for their origin communities. Institutional arrangements, including the hukou system and associated social welfare system, give rise to the structural exclusion of rural migrants. Unlike in many other settings where migrants eventually sever social ties, ${ }^{85}$ this exclusion motivates migrants' activism while sustaining attachment to home communities. ${ }^{86}$ State institutions also lead to a massive rural-urban information divide. In this context, migration helps to open political spaces for those of a rural background. The confluence of these conditions places migrants in a unique position to impart new political consciousness and action into home communities. In a way, the structural restrictions that have marginalized peasants and migrants paradoxically emancipate many of them.

What do our findings suggest about the future of rural resistance? It is still too early to tell if migrants will emerge as a source of fundamental political change in rural China. A limiting factor is the cellular nature of migrant and rural activism, which is locally oriented, short-lived, and centred on narrow economic claims and remedial measures. ${ }^{87}$ These actions rarely escalate into class movements or trans-local struggles, and they are almost never directed at instituting broader changes for improving the collective rights of migrants and peasants. For this reason, migrants and peasants face a fundamental challenge: a lack of institutionalized collective interests and the bargaining power necessary for sustaining gains. Even in Wukan, once the protests subsided, villagers failed to restore much of the disputed land, the autonomous village committee was absorbed by higher-level governments, and key leaders fell victim to political retaliation. ${ }^{88}$

Still, there are reasons to expect that migrants will affect rural political development in the years ahead. At the moment, the first generation of migrants are retiring and returning home. ${ }^{89}$ Second-generation migrants have come of age. While many are determined to reside in cities, they are nonetheless thwarted by structural barriers. This is compounded by a general 
pattern of migration involving shorter distances. ${ }^{90}$ In the meantime, both generations of migrants face increasing economic slowdown, which leads to factory closures and a growing wave of return migration. ${ }^{91}$ For those who return, land is a critical asset and can become a source of contention. A recent report shows that land disputes related to return migrants increased by 125 per cent between 2007 and 2008. ${ }^{92}$

All the patterns predict persistent connections between many migrants and their origin communities. ${ }^{93}$ The connections subsequently foster the political salience of migrants. The importance of migrants as an interpersonal political resource may well grow in the face of a recent tightening of information on official and social media. Several recent developments among Chinese migrants warrant attention. Migrants have become more assertive and proactive in defending their rights and increasingly press for collective benefits. Over time, they may reshape popular resistance in rural China in similar ways.

\section{Acknowledgement}

The authors thank Ran Tao, Guobin Yang, Shamus Khan, and the anonymous reviewers for their helpful comments at various stages of this research.

\section{Biographical notes}

Yao $\mathrm{Lu}$ is associate professor of sociology and faculty affiliate of the Weatherhead East Asian Institute at Columbia University. Her research focuses on the dynamics and consequences of migration, and particularly how internal migration shapes social and political development in China. Her recent work also examines the organizational basis of collective resistance, as well as the well-being of migrant children and left-behind children in China.

Wenjuan Zheng is a PhD candidate in the department of sociology at the City University of New York Graduate Center. She is interested in civil society, organizations, social movements and migration in China.

Wei Wang is a $\mathrm{PhD}$ candidate at the Annenberg School for Communication and Journalism at the University of Southern California. She is interested in online activism, digital capitalism and rural change in China.

摘要：通过对乌坎事件的个案研究和对多个省市农民及农民工的访谈, 本文旨在探讨农民 工对其流出地（中国农村）民众抗争的影响。通过研究发现农民工并非完全脱离其流出 地, 而是在农村抗争中发挥了多重作用。他们向农村社区传递新信息和新观念, 有时返乡 参与或领导村民抗争。农民工的传播和参与有助于提升农民的权利意识和政治参与。他们 的作用在乌坎事件中尤为显著, 但并非局限于乌坎。总而言之, 农民工是一股不可忽视的 潜在政治力量, 尤其当流出地出现土地纠纷等情况, 他们的作用即有可能被激发。本文提 供了一个理解中国民众抗争的传播以及城市与农村抗争之间关联的视角。

关键词：迁移；农民工；抗争；抗议；农村；乌坎

\section{References}

Bernstein, Thomas P., and Xiaobo Lü. 2003. Taxation without Representation in Contemporary Rural China. Cambridge: Cambridge University Press. 
Cai, Yongshun. 2010. Collective Resistance in China: Why Popular Protests Succeed or Fail. Stanford, CA: Stanford University Press.

Chan, Chris King-Chi, and Ngai Pun. 2009. "The making of a new working class? A study of collective actions of migrant workers in South China." The China Quarterly 198, 287-303.

Chan, Kam Wing. 2013. "China: internal migration." In The Encyclopedia of Global Human Migration. Blackwell Publishing online. DOI: 10.1002/9781444351071.wbeghm124.

China Digital Times. 2014. "Wukan youth: Zhang Jianxing," 19 June, http://chinadigitaltimes.net/2014/06/wukan-youth/. Accessed 15 January 2015.

Démurger, Sylvie, and Hui Xu. 2011. "Return migrants: the rise of new entrepreneurs in rural China." World Development 39(10), 1847-61.

Eng, Irene, and Yi-Min Lin. 2002. "Religious festivities, communal rivalry, and restructuring of authority relations in rural Chaozhou, Southeast China." The Journal of Asian Studies 61(4), 1259-85.

Givan, Rebecca Kolins, Kenneth M. Roberts and Sarah A. Soule. 2010. "Introduction: the dimensions of diffusion." In Rebecca Kolins Givan, Kenneth M. Roberts and Sarah A. Soule (eds.), The Diffusion of Social Movements: Actors, Mechanisms, and Political Effects. New York: Cambridge University Press, 1-15.

He, Shenjing, and Desheng Xue. 2014. "Identity building and communal resistance against landgrabs in Wukan village, China." Current Anthropology 55(S9), S126-S137.

$\mathrm{Hu}$, Feng, Zhaoyuan $\mathrm{Xu}$ and Yuyu Chen. 2011. "Circular migration, or permanent stay? Evidence from China's rural-urban migration." China Economic Review 22(1), 64-74.

Jacobs, Andrew. 2011. "Chinese village of Wukan locked in rebellion against authorities," The New York Times, 14 December, http://www.nytimes.com/2011/12/15/world/asia/chinesevillage-locked-in-rebellion-against-authorities.html. Accessed 15 December 2014.

Kolo, K., and Shuijie Zhang. 2012. "Wukan: citizens fight to keep land," Human Rights in China, 18 December, http://www.hrichina.org/en/crf/article/6454. Accessed 20 November 2014.

Kong, Sherry Tao, Xin Meng and Dandan Zhang. 2010. "The global financial crisis and ruralurban migration.” In Ross Garnaut, Jane Golley and Ligang Song (eds.), China: The Next Twenty Years of Reform and Development. Canberra: The Australian National University, 241-265.

Lee, Ching Kwan. 2007. Against the Law: Labor Protests in China's Rustbelt and Sunbelt. Berkeley, CA: University of California Press.

Li, Lianjiang. 2010. "Rights consciousness and rules consciousness in contemporary China." The China Journal 64, 47-68.

Li, Lianjiang, and Kevin J. O'Brien. 2008. "Protest leadership in rural China." The China Quarterly 193, 1-23.

Liang, Zai, Zhen Li and Zhongdong Ma. 2014. "Changing patterns of the floating population in China, 2000-2010." Population and Development Review 40(4), 695-716.

Lie, Anne Christine. 2014. "Rethinking Rural Resistance in China: A Case Study of the 2011 Wukan Incident in Guangdong Province.” M.A. Thesis, University of Oslo.

Liu, Jun. 2015. "The dynamics of real-time contentious politics: how ubiquitous internet shapes and transforms popular protests in China." In Anja Bechmann and Stine Lomborg (eds.), The Ubiquitous Internet: User and Industry Perspectives London: Routledge, 74-96. 
Liu, Li-Juan, and Qiang Guo. 2007. "Loneliness and health-related quality of life for the empty nest elderly in the rural area of a mountainous county in China." Quality of Life Research 16(8), 1275-80.

O'Brien, Kevin, and Lianjiang Li. 2006. Rightful Resistance in the Chinese Countryside. New York: Cambridge University Press.

Perry, Elizabeth J. 2009. "A new rights consciousness?” Journal of Democracy 20(3), 17-20.

Qiu, Jack Linchuan. 2009. Working-class Network Society: Communication Technology and the Information Have-less in Urban China. Cambridge, MA: MIT Press.

Solinger, Dorothy J. 1999. "Citizenship issues in China's internal migration: comparisons with Germany and Japan." Political Science Quarterly 114, 455-478.

Tang, Wenfang, and Qing Yang. 2008. "The Chinese urban caste system in transition." The China Quarterly 196, 759-779.

Tomba, Luigi. 2005. "Residential space and collective interest formation in Beijing's housing disputes." The China Quarterly 184, 934-951.

Waldinger, Roger. 2015. The Cross-border Connection: Immigrants, Emigrants, and their Homelands. Cambridge, MA: Harvard University Press.

Wang, Jianhua. 2011. "Mobilizing on the internet and the protest of foundry workers." Open Times 11, 114-128.

Wong, Edward. 2011. "Canny Wukan villagers grasp keys to loosen China's muzzle," The New York Times, 22 December, http://www.nytimes.com/2011/12/23/world/asia/canny-wukanvillagers-grasp-keys-to-loosen-chinas-muzzle.html. Accessed 15 December 2014.

Yang, Guobin. 2009. The Power of the Internet in China: Citizen Activism Online. New York: Columbia University Press.

Zeng, Zhimin. 2013. "Wukan: the whole story." The China Nonprofit Review 5, 17-101.

Zhang, Isabelle. 2012. "Wukan - a symbol of popular resistance," 24 March, http://www.internationalviewpoint.org/spip.php?article2548. Accessed 31 October 2015.

Zhang, Wu. 2015. "Protest leadership and state boundaries: protest diffusion in contemporary China." The China Quarterly 222, 360-379.

Zhu, Yu. 2007. "China's floating population and their settlement intention in the cities: beyond the Hukou reform." Habitat International 31(1), 65-76. 


\section{Figure 1: Roles of Migrants}

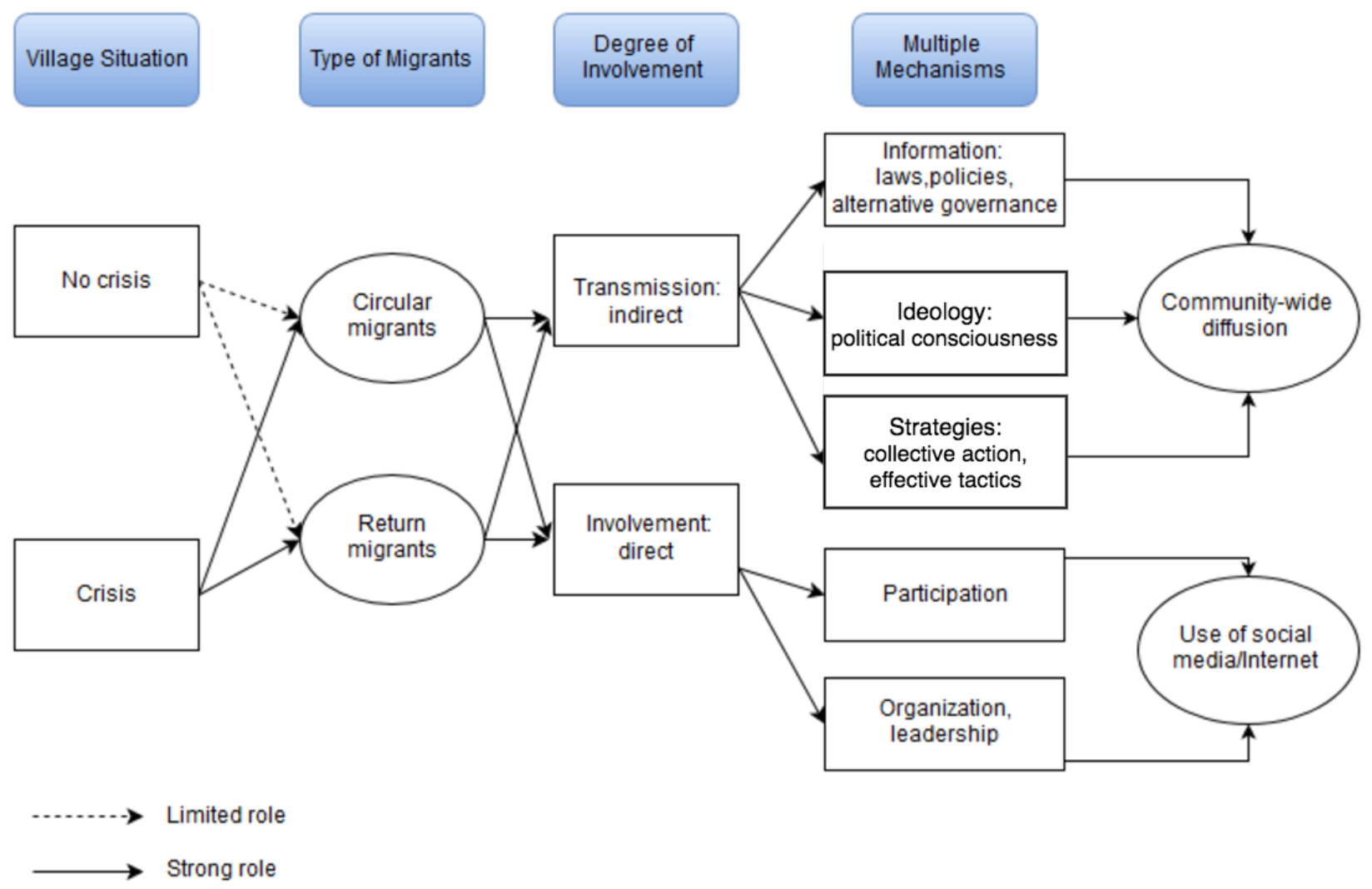

\footnotetext{
${ }^{1}$ Jacobs 2011. We use the terms "popular resistance" and "rural resistance" interchangeably to refer to the form of individual or collective action most common in rural China. The resistance involves peasant defiance of official malfeasance.

${ }^{2}$ Kolo and Zhang 2012; Zhang, Isabelle 2012; Lie 2014; Liu, Jun 2014.

${ }^{3}$ National Bureau of Statistics. 2014. "2013 nian quanguo nongmingong diaocha baogao" (A report on migrant workers in 2013), http://www.stats.gov.cn/tjsj/zxfb/201405/t20140512_551585.html. Accessed 31 October 2015.

${ }^{4}$ Chan, Kam Wing 2013.

${ }^{5}$ Solinger 1999.

${ }^{6}$ Zhu 2007.

${ }^{7}$ Bernstein and Lü 2003; O’Brien and Li 2006; Lee 2007; Cai 2010.

${ }^{8}$ Tomba 2005; Lee 2007.

${ }^{9}$ Qiu 2009; Yang 2009; Wang 2011.

${ }^{10}$ Tang and Yang 2008; Chan and Pun 2009.

${ }^{11}$ Bernstein and Lü 2003; O’Brien and Li 2006; Cai 2010.

${ }^{12}$ O'Brien and Li 2006; Cai 2010.

${ }^{13}$ Bernstein and Lü 2003.

${ }^{14}$ Zhang, Wu 2015.

${ }^{15}$ Givan, Roberts and Soule 2010.

${ }^{16} \mathrm{Li}$ and O'Brien 2008; Bernstein and Lü 2003.

${ }^{17}$ Liang, Li and Ma 2014.

${ }^{18}$ Kolo and Zhang 2012.

${ }^{19} \mathrm{He}$ and Xue 2014.
} 
${ }^{20}$ The open letter is available at http://cnlaf.blogspot.com/2011/09/blog-post_29.html. Accessed 5 December 2016.

${ }^{21}$ Lie 2014.

${ }^{22}$ Wang, Sally. 2012. "20 years of anger unleashed," South China Morning Post, 2 January, http://www.scmp.com/article/989180/20-years-anger-unleashed. Accessed 15 December 2014

${ }^{23}$ To see the documentary, go to https://www.youtube.com/watch? $\mathrm{v}=\mathrm{Lb} \_$tto2GwoU.

${ }^{24}$ Zhang, Isabelle 2012.

${ }^{25}$ Ibid.

${ }^{26}$ Jacobs 2011.

${ }^{27}$ He and Xue 2014.

${ }^{28}$ Interview with Huang, Wukan, May 2015.

${ }^{29}$ Zhang, Isabelle 2012; Hui, Echo. 2014. "Chinese authorities just won't give up, says Wukan protest leader who fled to US," South China Morning Post, 26 March, http://www.scmp.com/news/china/article/1457311/wukanprotest-leader-fled-us-fearing-safety. Accessed 10 January 2015; interview with Zhuang Liehong, New York, March 2015.

${ }^{30}$ Interview, Zhuang Liehong.

${ }^{31} \mathrm{Wu}$, Liwei. 2012. "Wukan cun rudi jiufen yu zongzu zhizheng" (Land disputes in Wukan village and conflicts between clans), 3 January, http://m.aisixiang.com/data/48761-2.html. Accessed 31 October 2015.

${ }^{32}$ Interview, Zhuang Liehong.

${ }^{33}$ Ibid.

${ }^{34}$ Ibid.

${ }^{35}$ Ibid.

${ }^{36}$ Zeng 2013; Lie 2014.

${ }^{37}$ Interview, Zhuang Liehong; China Digital Times 2014.

${ }^{38}$ Zhang, Isabelle 2012.

${ }^{39} \mathrm{He}$ and Xue 2014.

${ }^{40}$ Clans, formed along patrilineal kinship ties, represent a principal informal institution in rural China. Even in rural China today, clans remain an important source of collective identity and solidarity, which can be mobilized in times of need. Zhang, Isabelle 2012; He and Xue 2014.

${ }^{41}$ Interview, Zhuang Liehong.

${ }^{42}$ Zhu 2007.

${ }^{43}$ Démurger and $\mathrm{Xu} 2011$.

${ }^{44}$ Wong 2011.

${ }^{45} \mathrm{Li}$ and O'Brien (2008) and Bernstein and Lü (2003) both discuss the role of demobilized soldiers (fuyuan junren) play as protest leaders and a source of information in rural China. Their discussion does not focus on migrants specifically, but the experience of migration lurks in the background of the stories.

${ }^{46}$ Beitarie, Rachel. 2011. "The spirit of Wukan," 23 December, http://foreignpolicy.com/2011/12/23/the-spirit-ofwukan/. Accessed 31 October 2015.

${ }^{47}$ Liu, Jianfeng. 2012. "Wukan mima" (Wukan password), 9 June, http://www.eeo.com.cn/2012/0609/228009.shtml. Accessed 31 October 2015.

${ }^{48}$ Wong 2011.

${ }^{49}$ Interview, Zhuang Liehong.

${ }^{50}$ Ibid.

${ }^{51} \mathrm{He}$ and Xue 2014.

${ }^{52}$ Eng and Lin 2012.

${ }^{53}$ Interview, Huang.

${ }^{54} \mathrm{He}$ and Xue 2014.

${ }^{55}$ Ibid.

${ }^{56}$ Chin, Josh. 2012. "Wukan elections the spark to set the prairie ablaze?" 1 February, http://blogs.wsj.com/chinarealtime/2012/02/01/china-wukan-elections-the-spark-to-set-the-prairie-ablaze/. Accessed 31 October 2015; Zeng 2013.

${ }^{57}$ China Digital Times 2014.

${ }^{58}$ Interviews with Zhuang; Huang.

${ }^{59}$ Interview with Zhuang.

${ }^{60}$ China Digital Times 2014.

${ }^{61}$ According to our interview with Huang, this message was circulated widely among the QQ groups. 
${ }^{62}$ Interview, Huang.

${ }^{63}$ Interview with SZ01, a migrant worker, Shenzhen, April 2015.

${ }^{64}$ Interview with SZ07, a migrant worker, Shenzhen, April 2015.

${ }^{65}$ Interview, SZ01; interview with SZ06, a migrant worker, Shenzhen, April 2015.

${ }^{66}$ Interview with SZ04, a leader of a labour nonprofit organization, Shenzhen, May 2015.

${ }^{67}$ Interview with SZ05, a migrant worker, Shenzhen, April 2015.

${ }^{68}$ Interview, SZ06.

${ }^{69}$ Interview with SZ03, a migrant workers, Shenzhen, April 2015.

${ }^{70}$ Interview with SZ09, a migrant worker, Shenzhen, April 2015.

${ }^{71}$ Ibid.

${ }^{72}$ Interview with HN01, the wife of Shenzhen migrant SZ09.

${ }^{73}$ Ibid.

${ }^{74}$ Interview with JS01, a villager, Jiangsu, March 2015.

${ }^{75}$ Interview with FJ02, a villager (return migrant), Fujian, May 2015. He reflected on the experience while he was a migrant.

${ }^{76}$ Interview, SZ06.

${ }^{77}$ Interview with FJ03, a villager, Fujian, April 2015.

${ }^{78}$ Interview with JS03, a villager, Jiangsu, March 2015.

79 Perry 2009.

${ }^{80} \mathrm{Li} 2010$.

${ }^{81}$ Interview with HZ01, a migrant worker, Hangzhou, June 2015.

${ }^{82}$ Interview with FJ04, a villager, Fujian, April 2015.

83 "Chinese voice anger and nostalgia over urbanization," www. nytimes.com, 15 June 2013, http://www.nytimes.com/interactive/2013/06/16/world/asia/weibo-voices-land-seizures.html. Accessed 21 March 2016.

${ }^{84}$ Liu, Li-Juan, and Guo 2007.

${ }^{85}$ Waldinger 2015.

${ }^{86} \mathrm{Hu}, \mathrm{Xu}$ and Chen 2011.

${ }^{87}$ Lee 2007; Cai 2010.

${ }^{88}$ Tiezzi, Shannon. 2014. "Democracy with Chinese characteristics: the case of Wukan," 3 April, http://thediplomat.com/2014/04/democracy-with-chinese-characteristics-the-case-of-wukan/. Accessed 15 November 2014.

${ }^{89}$ Liang, Li and Ma 2014.

90 Ibid.

${ }^{91}$ Kong, Meng and Zhang 2010; Kessel, Jonah M. 2016. "His factory job gone, a Chinese migrant worker returns home," The New York Times, 19 January, http://www.nytimes.com/2016/01/20/world/asia/china-guangdongeconomy.html. Accessed 1 April 2016.

92 Shi, Shan. 2009. "Nongmingong shiye jiaju nongdi jiufen" (Unemployment of migrants intensifies land disputes), 3 April, http://www.rfa.org/mandarin/yataibaodao/nongmin-03042009101652.html. Accessed 1 April 2016.

${ }^{93}$ Interviews, Zhuang; Huang; SZ01; and SZ07. 